$2-1-2020$

\title{
Acute and long-term manganese exposure and subsequent accumulation in relation to idiopathic blindness in the American lobster, Homarus americanus
}

\author{
Addison T. Ochs \\ Virginia Institute of Marine Science \\ Jeffrey D. Shields \\ Virginia Institute of Marine Science \\ Gary W. Rice \\ Michael A. Unger \\ Virginia Institute of Marine Science
}

Follow this and additional works at: https://scholarworks.wm.edu/vimsarticles

Part of the Aquaculture and Fisheries Commons

\section{Recommended Citation \\ Ochs, Addison T.; Shields, Jeffrey D.; Rice, Gary W.; and Unger, Michael A., "Acute and long-term manganese exposure and subsequent accumulation in relation to idiopathic blindness in the American lobster, Homarus americanus" (2020). VIMS Articles. 1835. \\ https://scholarworks.wm.edu/vimsarticles/1835}

This Article is brought to you for free and open access by the Virginia Institute of Marine Science at W\&M ScholarWorks. It has been accepted for inclusion in VIMS Articles by an authorized administrator of W\&M ScholarWorks. For more information, please contact scholarworks@wm.edu. 


\section{Acute and long-term manganese exposure and subsequent accumulation in relation to idiopathic blindness in the American lobster, Homarus americanus}

Addison T. Ochs ${ }^{1}$, Jeffrey D. Shields*¹, Gary W. Rice ${ }^{2}$, Michael A. Unger ${ }^{1}$

${ }^{1}$ Virginia Institute of Marine Science, The College of William and Mary, P.O. Box 1346, Gloucester Point, VA 23062, USA

${ }^{2}$ Chemistry Department, The College of William and Mary, Williamsburg, VA 23187

*Corresponding author: jeff@vims.edu (J.D. Shields)

\section{Abstract}

Manganese (Mn) is a hypoxic reactive metal commonly found in marine sediments. Under hypoxic conditions the metal becomes fully reduced to $\mathrm{Mn}^{2+}$ and is biologically available to the benthic community for uptake. $\mathrm{Mn}$ is also a potent neurotoxin and it may play a role in the etiology of idiopathic blindness that has been observed in American lobsters. An acute study was designed to expose American lobster, Homarus americanus, to 0, 20, 80, 150, and $300 \mathrm{mg} \mathrm{Mn} \mathrm{L}^{-}$ ${ }^{1}$ (ppm) for 96 hrs to explore disparities in Mn accumulation among several tissues: optic nerve, brain, hepatopancreas, muscle, hemolymph, gill, and exoskeleton. These concentrations were based on realistic pore-water concentrations $\left(20 \mathrm{mg} \mathrm{L}^{-1}\right)$, high sediment concentrations (80 $\mathrm{mg} \mathrm{L}^{-}$ ${ }^{1}$ ), and unrealistically high concentrations to determine lethality (150 and $300 \mathrm{mg} \mathrm{L}^{-1}$ ). A positive correlation between $\mathrm{Mn}$ accumulation and exposure concentration was observed in all tissues examined. In the internal tissues, manganese concentrations showed a high affinity towards brain, optic nerve, and hemolymph. In the exoskeleton and gills, Mn concentrations were also high, possibly because of internal uptake as well as external adsorption. Concentrations of Mn in tissues from the acute exposure study followed the pattern: hemolymph > gill > exoskeleton > optic nerve $>$ brain $>$ hepatopancreas $=$ muscle. A long-term exposure study lasting seven weeks 
was designed to investigate the potential link between high Mn exposure and idiopathic blindness, a condition that affects an estimated 50\% of the adult American lobster population off Southern New England (SNE), USA. A comparison of these exposure studies showed evidence of time-dependent Mn accumulation in brain, muscle, exoskeleton, and gill tissue. Although the relationship between $\mathrm{Mn}$ exposure and blindness was not apparent, there was a modest trend in the development of blindness (Chi-square, $\mathrm{p}=0.102$ ) in animals exposed to a high concentration (150 $\mathrm{mg} \mathrm{L}^{-1}$ ) of the metal. With no mortalities occurring in the acute study and only one mortality in the long-term study, it is highly unlikely that Mn is acutely toxic to American lobsters at environmentally relevant concentrations. Its potential role in idiopathic blindness remains to be determined.

Key words: idiopathic blindness, causality, metal exposure, hypoxia, anoxia, Crustacea

\section{Introduction}

Manganese ( $\mathrm{Mn})$ is frequently present in benthic marine sediments as $\mathrm{MnO}_{2}$. During hypoxic events $\mathrm{Mn}$ becomes fully reduced to its divalent form $\left(\mathrm{Mn}^{2+}\right)$ as the oxygen is scavenged from $\mathrm{MnO}_{2}$ for microbial respiration. Fully reduced manganese is the major bioavailable fraction in the environment. $\mathrm{Mn}^{2+}$ is released from the sediments via diffusion into the water column and surrounding pore water where concentrations have been reported as high as $1.5 \mathrm{mg} \mathrm{L}^{-1}$ and 20 mg L ${ }^{-1}$, respectively (Aller, 1994; Magnusson et al., 1996); albeit the pore water concentration approaching $600 \mu \mathrm{M}$ (33.6 $\mathrm{mg} \mathrm{L}^{-1}$ ) have been reported (Bartlett et al. 2007). The inshore waters of Long Island Sound (LIS) and Narragansett Bay experience seasonally intense hypoxic events lasting from days to weeks allowing for prolonged $\mathrm{Mn}^{2+}$ exposure in the benthos. Although other areas of LIS and Rhode Island Sound (RIS) do not experience significant water-borne hypoxia, 
their benthic substrates still experience reducing conditions, releasing $\mathrm{Mn}^{2+}$ into pore water (Aller, 1994; Mecray and Buchholtz ten Brink, 2000). Moreover, lobsters can receive significant exposure to $\mathrm{Mn}^{2+}$ even when overlying waters are normoxic, reaching levels as high as $385 \mathrm{mg}$ $\mathrm{L}^{-1}$ in the gills of animals held in situ in areas with benthic hypoxia (Draxler et al. 2005).

Idiopathic blindness was first described in the American lobster, Homarus americanus following the 1999 mortality event in Long Island Sound (Magel et al., 2009; Maniscalco and Shields, 2006). This condition has an unknown etiology but arises as a result of degenerative changes to the individual elements of the compound eye, namely the ommatidia cells and optic nerves. Prevalence levels $>50 \%$ have been reported throughout the Southern New England (SNE) population, with much lower prevalence levels and severities in lobsters from the Gulf of Maine (Ochs et al., 2018; Shields et al., 2012). Previous studies have shown that when blindness is present in an animal, the probability is high that the condition has manifested in both eyes and at similar severities (Maniscalco and Shields, 2006; Ochs et al., 2018). Moreover, cases of moderate to severe blindness often exhibit symmetrical lesions, with the lesions in the left eye resembling a mirror image of the lesions in the right eye. Lesions often occur in the extreme lateral regions of the eye in mild cases ( $<10 \%$ affected area). In moderate cases $(10-30 \%$ affected area), these lesions can extend to the medial-lateral regions and in severe cases $(>30 \%$ affected area), they appear to coalesce, spanning the width of the eye in a banding pattern (Fig. 1). The presence of the lesions has been shown to severely impact vision, with moderately affected individuals experiencing a near complete loss of vision (Magel et al., 2009). The effect of blindness on other aspects of lobster health has not been fully investigated. The etiology of this disease is likely linked to environmental factors such as rising temperatures, contaminants, hypoxic events, heavy metals, or a combination of these. 
Manganese is of particular interest in the etiology of blindness as it is a hypoxic reactive metal released from sediments during benthic hypoxic events, exposing lobsters in burrows to significant, biologically available concentrations of the metal (Aller, 1994; Draxler et al., 2005; Wollast et al., 1979). Mn can accumulate in the brains of pike (Esox lucius) and elicit cytoxic and genotoxic effects in gold fish (Carassius auratus) (Tjälve et al., 1995; Aliko et al., 2018). Mn also rapidly accumulates in nervous tissue and hemolymph of the Norway lobster, Nephrops norvegicus, with corresponding effects on biological processes including immunosuppression, impaired hemocyanin synthesis, and decreases in both neuromuscular contractile force and posttail flip extension (Baden et al., 1999; Baden and Neil, 1998; Hernroth et al., 2004; Holmes et al., 1999; Oweson et al., 2006). Natural levels of Mn in lobsters have also been correlated with increased temperature (Eriksson \& Baden, 1998), particularly in areas with low oxygen concentration (Eriksson, 2000). It is also known to accumulate in the gills of American lobsters, H. americanus, during seasonal hypoxia (Draxler et al. 2005). In addition, $\mathrm{Mn}^{2+}$ is a wellestablished neurotoxin (Couper, 1837) as it induces DNA fragmentation, successive apoptosis in neuronal cells (Aschner \& Aschner, 1991; Hirata, 2002), and accumulates at high levels in nerve tissues of $N . n$ The effect of blindness on other aspects of lobster health has not been fully investigated. orvegicus (Baden et al., 1999; Baden \& Eriksson, 2006; Baden \& Neil, 1998). Mn is also readily found in high concentrations in benthic sediment throughout LIS and Narragansett Bay (Aller, 1994; Mecray and Buchholtz ten Brink, 2000).

Given the possible relationship between Mn and blindness, our objectives were to: (1) Identify target tissues for manganese accumulation in Homarus americanus; (2) assess possible lethal effects in relation to Mn concentration; and (3) investigate the etiology of idiopathic blindness and the role that $\mathrm{Mn}^{2+}$ is believed to play in the development of the condition. 


\section{Methods}

\subsection{Collection of animals for exposure studies}

American lobsters were collected by personnel from the Division of Marine Fisheries, Massachusetts, and the Dept. Marine Resources, Maine as part of their ventless trap surveys in areas that were not experiencing seasonal hypoxia. Lobsters in the acute exposure study were collected in October, 2018, from Massachusetts Bay; those in the long-term exposure study were collected in August, 2018, from Casco Bay, Maine. Animals were shipped covered with moist paper and on ice overnight to the Virginia Institute of Marine Science, where they were held in aquaria with artificial seawater (Marine Mix) at 35 psu. Prior to their use in experiments, the animals were acclimated to the vivarium setting for 10 days at $15^{\circ} \mathrm{C}$. Temperatures were increased slowly from $15^{\circ} \mathrm{C}$ to $18^{\circ} \mathrm{C}$ for the acute study and $17^{\circ} \mathrm{C}$ for the long-term study. Animals were held in 20L seawater in individual 38L aquaria equipped with Whisper bio-filters and air stones. The Whisper bio-filters were removed prior to the exposure studies.

\subsection{Water}

Seawater was mixed a minimum of 24 hours prior to its use and stored in a large 1890 L (500 gal.) recirculating tank with its own in-line chiller $\left(18^{\circ} \mathrm{C}\right)$ and aeration. Manganese (II) Chloride Tetrahydrate (Sigma-Aldrich SLBX9249) was dissolved in approximately $500 \mathrm{ml}$ of DI water the morning of a water change. The Mn solution was mixed with seawater in several 121 to 208 L plastic bins to achieve a final concentration before being added to aquaria containing animals. To avoid confounds in exposure concentrations, each mixing bin was assigned to a specific 
treatment throughout the studies. Water pumps were assigned to either control groups or Mn groups for the duration of the studies.

\subsubsection{Acute exposure study}

An initial acute exposure study was designed to examine accumulation of $\mathrm{Mn}$ and potential lethal effects of the metal. Five treatment groups were used at the following concentrations of manganese: $0 \mathrm{mg} \mathrm{L}^{-1}$ (control), $20 \mathrm{mg} \mathrm{L}^{-1}$ (highest reported pore-water concentration), $80 \mathrm{mg} \mathrm{L}^{-1}$ (high concentration reported from sediments), $150 \mathrm{mg} \mathrm{L}^{-1}$ (range finding for sublethal or lethal effects), and $300 \mathrm{mg} \mathrm{L}^{-1}$ (range finding for sublethal or lethal effects). Six lobsters were held in each experimental treatment with an additional two lobsters in the $300 \mathrm{mg} \mathrm{L}^{-1}$ treatment for a total of 32 lobsters. The additional animals were included in the $300 \mathrm{mg} \mathrm{L}^{-1}$ treatment to improve sample size in the event of mortality. When no mortality occurred at 96 hrs, the two extra animals were moved to aquaria with clean seawater for an additional 72 hrs to obtain preliminary information on Mn depuration. To avoid independence artifacts, the lobsters were held individually in 20L of seawater in 38L aquaria aerated with airstones. Aquaria were housed in two large recirculating water baths. Each water bath was held at $18{ }^{\circ} \mathrm{C}$. Lobsters were checked daily for morbidity and mortality. Water changes were conducted every 48hrs with 100\% renewal. Duplicate water samples were taken from randomly selected tanks within each treatment before and after water changes to measure variability in Mn concentrations (see Table 1 for mean values). Lobsters remained unfed over the course of the experiment.

\subsubsection{Blindness assessment}

Lobsters in both the acute and long-term studies were assessed for blindness using the noninjurious method developed by Ochs et al. (2018). Briefly, the eye of each lobster was examined 
with an otolaryngoscope (hereafter, o-scope) before and after exposure. For the long-term exposure study, lobsters were assessed with the o-scope prior to exposure, and again at one-week intervals for the duration of the study. The lesions associated with blindness were recorded and their relative size was estimated as a percentage of the total area of the compound eye.

\subsection{Long-term exposure study}

Because exposure to $300 \mathrm{mg} \mathrm{L}^{-1} \mathrm{Mn}$ after 4 days did not result in lobster mortality, but did leave a precipitate in the aquaria, a concentration of $150 \mathrm{mg} \mathrm{L}^{-1} \mathrm{Mn}$ was used for the long-term exposure study. To examine whether long-term exposure to Mn may result in blindness, 10 lobsters were exposed to $150 \mathrm{mg} \mathrm{L}^{-1} \mathrm{Mn}$ for 7 weeks at $17^{\circ} \mathrm{C}$. Lobsters were assessed with the oscope for signs of blindness before the experiment, after two weeks, and weekly thereafter until the end of the experiment. Given that idiopathic blindness may take years to develop in animals exposed to low, sublethal concentrations of Mn, we used an unrealistically high exposure concentration (150 mg L ${ }^{-1}$ ) in an effort to more quickly reveal possible links with the syndrome. A control group consisted of 8 animals not exposed to Mn, but otherwise handled in the same way. Lobsters were fed small amounts ( $2 \mathrm{~g}$ each) of squid every two weeks throughout the study. Lobsters were checked daily for mortalities. Water changes were done weekly with $100 \%$ renewal. Duplicate water samples were taken from randomly selected tanks within each treatment before and after water changes to measure variability in Mn concentration. At the end of the long-term exposure study, the lobsters were killed, dissected, and their eyes placed in Bouin's fixative for later histological assessment as described below.

\subsection{Metals analysis}


At the end of the exposure studies, all of the lobsters were killed. Hemolymph, muscle, exoskeleton (cuticle of the dorsal carapace), posterior gills, hepatopancreas, optic nerve, and brain were dissected and prepared for metals analysis via EPA Method 3050B (Modified). Briefly, tissues were placed individually in pre-weighed plastic sample tubes, weighed again, and then frozen and stored at $-80^{\circ} \mathrm{C}$. Tissue samples were later lyophilized for 72 hrs (see Table 1 for wet/dry weight data). Approximately $0.1-0.2 \mathrm{~g}$ of tissue were digested in 2-4 ml ACS grade concentrated nitric acid then diluted with ultra-pure deionized water to $20 \%$ nitric solutions. Digestions were achieved using an Environmental Express manual HotBlock SC196. Water and tissue samples were analyzed with a Perkin-Elmer atomic absorption spectrophotometer using both flame and graphite furnace atomization at the College of William and Mary. Standard reference material LUTS-1 (non-defatted lobster hepatopancreas) was analyzed to assess the validity of the digestion method. The National Research Council of Canada certifies LUTS-1 to contain $8.02 \pm 0.86 \mu \mathrm{g} \mathrm{Mn} \mathrm{g}{ }^{-1}$ dry wt. Analysis of the reference material produced a value of $8.17 \pm 0.17 \mu \mathrm{g} \mathrm{Mn} \mathrm{g}{ }^{-1}$ dry wt.

\subsection{Histological sampling of the eyes}

Histology remains the gold standard for detecting the presence of idiopathic blindness in lobsters. Histological sampling of the eyes was carried out according to Ochs et al. (2018). Briefly, eyes were fixed in Bouin's solution for at least 48 hrs. They were then decalcified in a sodium citrate/formic acid solution as in Luna (1968). The decalcified eyes were stored no longer than 6 hrs in 70\% ethanol before initiating the tissue process. Decalcified eyes were bisected using a clean, single-edge razor, and then processed for paraffin histology using a standard alcohol dehydration series. Sections were cut at $7 \mu \mathrm{m}$, deparaffinized,stained with 
Mayer's hematoxylin and eosin, processed through a dehydration series, and then mounted with Permount.

\subsection{Statistical analysis}

Statistical analysis was conducted in SYSTAT 11. A one-way ANOVA and the post hoc comparison, Tukey's HSD, was used to assess dissimilarities in Mn concentrations in each tissue type with respecft to exposure concentration. The homogeneity of variances was tested using Levene's test. The Shapiro-Wilk test was used to test normality. In cases where the data were not normally distributed, they were analyzed with and without square root and $\log _{10}$ transformations to meet the assumptions of ANOVA. Due to the exponential relationship between controls and exposure concentration, the assumption of linearity in response and the assumption of equal variances were the primary reasons for transformation. Pearson regression analysis of Mn accumulation in tissues in relation to exposure concentration was used to evaluate differences in slopes among tissues. Slopes are reported with respective 95\% confidence intervals.

\section{Results}

\subsection{Acute Exposure Study - General observations}

None of the animals in the acute exposure study died during the 96-hr course of the experiment. In the $300 \mathrm{mg} \mathrm{L}^{-1}$ exposure, a white flocculent precipitate developed shortly after the experiment started and formed a thin layer on animals and tanks. The flocculent was not present in the 150 $\mathrm{mg} \mathrm{L}^{-1}$ or lower exposures. Table 1 indicates that the nominal and the actual levels of $\mathrm{Mn}$ at 300 ppm were within $<5 \%$ error. In addition, filtrate from the 300 ppm treatments were consistently within 5\% of the nominal 300 ppm (data not shown, Ochs, unpublished data). The precipitate was not black as would be expected of a manganese oxide. 


\subsubsection{Acute exposure study}

Manganese concentrations in the tissues were positively correlated with increasing exposure concentration. Accumulation in muscle and hepatopancreas tissue was the least affected by increasing exposure concentration in comparison to other tissues. Accumulation in hemolymph was the most affected, with concentrations in the $300 \mathrm{mg} \mathrm{L}^{-1}$ exposure group reaching levels approximately 158 times those reported in control animals.

\section{Muscle}

Accumulation in the muscle was low with respect to other tissues, but showed a consistent pattern in relation to exposure concentration, with a plateau above $80 \mathrm{mg} \mathrm{L}^{-1}$ (Table 2). The raw data showed no significant difference in accumulation between the control group and the $20 \mathrm{mg}$ $\mathrm{L}^{-1}$ group (lowest treatment group) (ANOVA, $\mathrm{p}=0.495$ ), as well as no significant difference in accumulation between the $150 \mathrm{mg} \mathrm{L}^{-1}$ and $300 \mathrm{mg} \mathrm{L}^{-1}$ exposure groups (ANOVA, $\mathrm{p}=0.107$ ). Muscle data were transformed via $\log _{10}$ and square root transformations. The square root transformation yielded the best linear fit. Both transformations showed a highly significant difference between the control group and the $20 \mathrm{mg} \mathrm{L}^{-1}$ exposure group (ANOVA, $\mathrm{p}<0.001$ ), but no significant differences between the $150 \mathrm{mg} \mathrm{L}^{-1}$ and $300 \mathrm{mg} \mathrm{L}^{-1}$ groups (ANOVA, $\mathrm{p}=0.295$ and $\mathrm{p}=0.119$ respectively) (Fig. 2).

\section{Hepatopancreas}

Accumulation in the hepatopancreas was similarly low in comparison with muscle and followed its pattern with exposure concentration (Fig. 2, Table 2). Both raw and transformed data produced similar patterns. There was no significant difference between the control group and the $20 \mathrm{mg} \mathrm{L}^{-1}$ exposure group (ANOVA, $\mathrm{p}=0.078$ ), but the difference between the control group and 
the $80 \mathrm{mg} \mathrm{L}^{-1}$ exposure group was highly significant (ANOVA, $\mathrm{p}<0.001$ ). There was no significant difference between the $150 \mathrm{mg} \mathrm{L}^{-1}$ and $300 \mathrm{mg} \mathrm{L}^{-1}$ exposure groups (ANOVA, $\mathrm{p}=$ 0.527). The highest reported mean concentration occurred in the $300 \mathrm{mg} \mathrm{L}^{-1}$ exposure group at $81.38 \pm 14.17 \mu \mathrm{g} \mathrm{Mn} \mathrm{g}{ }^{-1} \mathrm{dw}$.

\section{Optic Nerve}

In contrast to the muscle and hepatopancreas, the accumulation of $\mathrm{Mn}$ in the optic nerve was high and continued to increase with exposure concentration (Fig. 2, Table 2). All comparisons of the treatment groups were highly significantly different (ANOVA, $\mathrm{p}<0.001$ ) with the exception of the $80 \mathrm{mg} \mathrm{L}^{-1}$ and $150 \mathrm{mg} \mathrm{L}^{-1}$ exposure groups which were not significantly different (ANOVA, $\mathrm{p}=0.731$ ). The highest mean concentration was reported in the $300 \mathrm{mg} \mathrm{L}^{-1}$ exposure group at $416.85 \pm 51.04 \mu \mathrm{g} \mathrm{Mn} \mathrm{g}^{-1} \mathrm{dw}$.

\section{Brain}

Although the accumulation of $\mathrm{Mn}$ in the brain was significantly higher than that in the muscle and hepatopancreas, the pattern of accumulation was similar, with a plateau in accumulation with increasing exposure concentration (Fig. 2). The control group was highly significantly different from the $20 \mathrm{mg} \mathrm{L}^{-1}$ exposure group (ANOVA, $\mathrm{p}<0.001$ ), but there was no significant difference between the $80 \mathrm{mg} \mathrm{L}^{-1}, 150 \mathrm{mg} \mathrm{L}^{-1}$, and $300 \mathrm{mg} \mathrm{L}^{-1}$ treatments (ANOVA, $\mathrm{p}=0.964$ ). The highest mean concentration was reported in the $150 \mathrm{mg} \mathrm{L}^{-1}$ exposure group at $207.67 \pm 43.41 \mu \mathrm{g} \mathrm{Mn} \mathrm{g}^{-1}$ dw.

\section{Hemolymph}

Of the internal tissues, hemolymph had the highest accumulation as well as the strongest linear response in relation to exposure concentration (Table 2). All treatment groups were significantly 
different from each other. The highest mean concentration was reported in the $300 \mathrm{mg} \mathrm{L}^{-1}$ exposure group with $1,525 \pm 72.87 \mu \mathrm{g} \mathrm{Mn} \mathrm{g}^{-1} \mathrm{dw}$.

\section{Gill}

The gill exhibited a strong linear correlation between Mn concentration and exposure concentration. The control group had significantly lower levels of Mn than that reported in all other groups, and the $300 \mathrm{mg} \mathrm{L}^{-1}$ treatment had the highest level of accumulation (Table 2). The highest mean concentration was reported in the $300 \mathrm{mg} \mathrm{L}^{-1}$ exposure group at $1262.21 \pm 116.60$ $\mu \mathrm{g} \mathrm{Mn} \mathrm{g}^{-1} \mathrm{dw}$.

\section{Exoskeleton}

Manganese concentrations in the exoskeleton were higher and more variable than in any other tissue in control animals (Table 2). Mn accumulation exhibited a positive increase in relation to exposure concentration. The control group was significantly lower than all other groups (ANOVA, $\mathrm{p}=0.001$ ). There were no significant differences between the $20 \mathrm{mg} \mathrm{L}^{-1}, 80 \mathrm{mg} \mathrm{L}^{-1}$,

and $150 \mathrm{mg} \mathrm{L}^{-1}$ exposure groups; however, the $300 \mathrm{mg} \mathrm{L}^{-1}$ treatment had significantly higher $\mathrm{Mn}$ concentrations than other treatments (ANOVA, $\mathrm{p}=0.011$ ). With square-root transformation, there was no change in the significance hierarchy, with the exception that the difference between the $150 \mathrm{mg} \mathrm{L}^{-1}$ and $300 \mathrm{mg} \mathrm{L}^{-1}$ treatments was highly significant $(\mathrm{p}<0.001)$. The highest mean concentration was reported in the $300 \mathrm{mg} \mathrm{L}^{-1}$ exposure group at $632.11 \pm 83.37 \mu \mathrm{g} \mathrm{Mn} \mathrm{g}^{-1} \mathrm{dw}_{\text {. }}$

\subsubsection{Analysis of accumulation slopes across tissue type}

All tissues showed a strong positive association with exposure concentration (Table 3). There were three distinct patterns within this association. Mn accumulation in muscle, hepatopancreas, and brain tissues had lower slopes in relation to exposure concentration than the other tissues. 
Their slopes were approximately one third of those found in optic nerve and exoskeleton. The slopes were more intermediate in the accumulation of $\mathrm{Mn}$ in the optic nerves and exoskeleton. The largest effect of exposure concentration on Mn accumulation was observed in gill and hemolymph tissue with slopes at least three and four times those reported in any other tissue.

\subsubsection{Observations on depuration}

Although the exposure studies were not designed to investigate the depuration of Mn, inferences can be made by examining the two extra animals in the $300 \mathrm{mg} \mathrm{L}^{-1}$ treatment of the acute exposure study. These animals were moved from the $300 \mathrm{mg} \mathrm{L}^{-1}$ exposure group to aquaria with clean artificial seawater at the termination of the study. They were allowed to depurate for $72 \mathrm{hrs}$ before dissection. Manganese concentrations in hepatopancreas, optic nerve, and brain showed no significant difference when compared to unexposed animals (Table 2). When compared to animals from the $300 \mathrm{mg} \mathrm{L}^{-1}$ exposure study, muscle, hepatopancreas, optic nerve, gill, and hemolymph in the depurated animals were all significantly lower in Mn concentration. Although not significant, a decreasing trend was also observed in brain tissue. The concentration of $\mathrm{Mn}$ in exoskeleton was not significantly different between the exposure and depurated animals.

\subsubsection{Long-term Exposure Study}

The premise for the long-term exposure study using a high concentration of Mn was to establish a model for Mn exposure to investigate its potential causal relation to idiopathic blindness in a realistic time frame. In natural systems, blindness likely develops over several years; Thus, it was necessary to first establish an appropriate exposure concentration for the laboratory. A high concentration that would not induce mortality would maximize the potential for any Mn related 
changes in the biology of the lobster. Exposure to high concentrations of manganese in the acute study did not result in any lobster mortalities, and the $300 \mathrm{mg} \mathrm{L}^{-1}$ concentration often left a flocculent precipitate in the aquaria that was not enriched for Mn. Nonetheless, for these reasons, the next highest concentration in the acute study $\left(150 \mathrm{mg} \mathrm{L}^{-1}\right)$ was used for the long-term exposure study. In addition, studies investigating light-induced blindness in N. norvegicus, indicate that an estimated 30-day developmental period is needed following exposure to sunlight before the histopathology associated with the condition becomes observable (Gaten, 1988; Shelton et al., 1985); therefore, the duration of the exposure was set $a$ priori at 4 to 8 weeks.

There was no difference in the hierarchy of soft tissue types between acute and long-term exposure studies with respect to Mn concentration. The pattern: Hemolymph > brain > hepatopancreas= muscle, was the same in both studies (Table 4). Manganese concentrations in brain, gill, and exoskeleton tissue were significantly higher in the long-term exposure study than in the acute exposure study $\left(150 \mathrm{mg} \mathrm{L}^{-1}\right)$. This is indicative of an effect of exposure duration on Mn accumulation in these tissues.

\subsubsection{Molting in the Long-term Exposure Study}

Four lobsters molted between the second and third week of the long-term exposure study. Although one of these animals died during ecdysis, the other three molted successfully and survived to the end of the experiment. Samples were taken from the exoskeletons of the old instars of these animals, as well as their new exoskeletons which were moderately hardened (molt stage $\mathrm{C}_{3}$ ) by the end of the experiment. The Mn concentration in the new exoskeletons was significantly higher than in animals from the same treatment that had not molted (Fig. 3). Within this same comparison, all other tissues were shown to be not significantly different. Therefore, the remaining tissues were pooled for comparison to the acute study. The exoskeleton data 
reported in the long-term study (Table 4) represents only non-molted animals from the exposure group.

\subsubsection{Mn concentrations between Acute and Long-term Exposure studies}

The Mn concentrations reported in the long-term exposure study were compared to the Mn concentrations reported in the $150 \mathrm{mg} \mathrm{L}^{-1}$ treatment group from the acute exposure study (Table 4). In all cases, Mn concentrations in the control group for the long-term exposure were significantly less than both the acute and long-term exposure treatments. Hepatopancreas and hemolymph tissues showed no difference in Mn concentration between the acute and long-term exposure groups (Fig. 4). Muscle and brain accumulated significantly more Mn in the long-term than the acute exposure (ANOVA, $\mathrm{p}=0.006$ and $\mathrm{p}<0.001$, respectively) (Fig. 4). The highest mean concentration in muscle tissue was reported in the long-term study at $118.95 \pm 10.96 \mu \mathrm{g}$ $\mathrm{Mn}^{-1} \mathrm{dw}$. The highest mean concentration in the brain tissue was reported in the long-term study at $410.96 \pm 40.58 \mu \mathrm{g} \mathrm{Mn} \mathrm{g}^{-1} \mathrm{dw}$. Similarly, the gill and exoskeleton accumulated significantly more $\mathrm{Mn}$ in the long-term exposure (ANOVA, $\mathrm{p}=0.004$ and $\mathrm{p}<0.001$, respectively). The highest mean concentration in gill tissue was reported in the long-term study at $1721.38 \pm$ $321.44 \mu \mathrm{g} \mathrm{Mn} \mathrm{g}^{-1} \mathrm{dw}$. The highest mean concentration in the exoskeleton tissue (non-molted) was reported in the long-term study at $3355.22 \pm 831.90 \mu \mathrm{g} \mathrm{Mn} \mathrm{g}^{-1} \mathrm{dw}$.

\subsubsection{Blindness in relation to exposure}

In the acute exposure study, the initial prevalence level of blindness using the o-scope was 9.37\% (3/32) of the animals and 4.69\% (3/64) of their eyes. The three cases of blindness had very light severity ( $\leq 1 \%$ affected area) levels. The animals were assessed again at 96 hours to 
obtain a final prevalence. As expected, no change in prevalence or severity was observed in the acute study.

Lobsters entering the long-term exposure study had an initial prevalence of blindness of $11.11 \%$ (2/18 animals) and 5.56\% (2/36 eyes). These animals were randomly assigned to treatment groups. No initial blindness was observed in the control animals. The initial prevalence in the exposure group was 20\% (2/10 animals) and 10\% (2/20 eyes). These eyes included one case of moderate blindness ( $10 \%$ affected area) and one case of mild blindness ( $\leq 1 \%$ affected area). The animals with blindness were removed from the statistical analysis, but their blindness was assessed throughout the experiment. At the end of the experiment, the final prevalence in the control group was $6.25 \%(1 / 16$ eyes) at $<1 \%$ area affected. The final prevalence in the exposure group was 33.33\% (3/9 animals) and 22.22\% (4/18 eyes). These eyes consisted of three mild cases of blindness $(\leq 4 \%$ affected area $)$ and one case of moderate blindness at $15 \%$ affected area. Over the course of the experiment, blindness accrued slowly in the exposed animals (Fig. 5) but there was no significant difference in the prevalence levels of blindness between treatments.

\subsubsection{Histological comparison}

The prevalence of blindness using histological diagnosis was 6.25\% (1/16 eyes) in the control group, and 44.44\% (4/9 animals) and 33.33\% (6/18 eyes) in the exposure group. Although there was no significant association between Mn exposure and blindness in the long-term exposure study, there was a potential trend (Chi-square, $\mathrm{p}=0.102, \mathrm{df}=1, \mathrm{n}=30$ ) of blindness in the exposure group compared with the control group when the previously blind animals were removed from the analysis. The histological assessment was in good agreement with the final o-scope assessment with a sensitivity of $71 \%$ and specificity of $100 \%$ (Table 5), with two additional 
cases of blindness detected via histological assessment. These two cases were mild in severity $(<1 \%$ affected $)$.

\section{Discussion}

This is the first study to investigate Mn accumulation in the American lobster, Homarus americanus, in a controlled laboratory setting. Lobsters tolerated high levels of $\mathrm{Mn}$ in both acute and long-term exposure studies. No mortalities occurred at any level of exposure over the course of the experiments with the exception of one lobster in the long-term study that died during molting. As expected there was differential accumulation of Mn in the disparate tissues. Accumulation of Mn in soft tissues followed the same pattern of affinity in both studies: hemolymph $>$ brain $>$ hepatopancreas $=$ muscle. The concentrations of $\mathrm{Mn}$ in the gills and exoskeleton were also high and were positively correlated with increasing exposure concentration, possibly due to accumulation in the tissues as well as external adsorption. We also examined the relationship between Mn exposure and idiopathic blindness in lobsters. Several animals developed blindness over the course of the long-term exposure, but the trend was not significant because the statistical power was too low to resolve differences. The duration of the acute study was too short to allow for the physiological development of blindness, therefore the lack of change in prevalence or severity of blindness was not unexpected in the study.

Manganese accumulation in the tissues of American lobster showed similar trends to those reported in the Norway lobster with three important differences. First, the exposure concentrations were markedly different between studies; hence the disparities may be due to wide differences in concentrations. Second, we show a time-dependent accumulation in brain and muscle tissues for $H$. americanus, a plateau was observed in many tissues of the Norway 
lobster (Baden \& Neil, 1998). A third, difference is the positive correlation observed between exposure concentration and Mn concentrations in the gills and exoskeleton of H. americanus. This correlation is not evident in exoskeleton and only suggested in gills of $N$. norvegicus (Baden et al., 1999), but was evident in environmental samples from areas experiencing various levels of hypoxia (Eriksson, 2000; Eriksson et al., 1998). Mn maintains a high affinity towards nervous tissue in both species, and the concentration of exposure is a major contributing factor with respect to Mn accumulation in many of the soft tissues. The Mn concentrations observed in the acute exposure study indicate a similar rapidity in accumulation and depuration rates between lobster species. Our observations concerning elimination agree with the findings of Baden et al. (1999) in which, the Mn depuration half-life ( $\left.\mathrm{T}_{1 / 2}\right)$ reported for brain, hemolymph, and hepatopancreas is between 24 and 72 hours.

The concentration of $\mathrm{Mn}$ in the hemolymph appears directly dependent on exposure concentration and not the duration of exposure. Manganese accumulation in the hemolymph showed a strong positive correlation with exposure concentration in the acute study, but no significant difference between the acute and long-term exposure studies. This direct proportionality between exposure concentration and Mn accumulation can be explained by rapid transport of $\mathrm{Mn}$ from the water, across the gills or antennules, and into the hemolymph. Hemolymph is a central compartment for Mn; and although the bioconcentration factor for it indicates an inverse relationship with exposure concentration, no plateau in uptake was observed as seen in the gill and exoskeleton (calculated from Table 1, excluding control values). This rapid and consistent uptake into the hemolymph indicates that it is the main route of $\mathrm{Mn}$ transport to other tissues within the lobster. Baden and Neil (1998) show that Mn binds to hemolymph proteins, specifically hemocyanin. Hemocyanin is the primary respiratory protein 
found in a vast majority of arthropod species and can contribute up to $90 \%$ of the protein fraction of hemolymph in decapod crustaceans (Uglow, 1969). Divalent Mn is believed to behave similarly to cadmium (Cd) in that it is able to bind to the calcium-binding sites of hemocyanin instead of competing for the copper-binding sites (Baden and Neil, 1998). At high concentrations, zinc and Cd have a higher binding affinity to hemocyanin and have been shown to replace calcium (Ca) in the hemolymph of the blue crab, Callinectes sapidus (Brouwer et al., 1983).

Accumulation of Mn in the hepatopancreas was positively correlated to exposure concentration. Although not always significant between adjacent treatments, this trend persisted across all treatment groups. Unlike in other soft tissues, Mn is known to slowly accumulate in the hepatopancreas over the duration of exposure. In the hepatopancreas of $N$. norvegicus, Baden et al. (1999) show a continuous accumulation of Mn over a 3-week exposure to 5 and $10 \mathrm{mg} \mathrm{L}^{-1}$ without reaching a plateau in concentration. However, in the present study there was not a significant difference in Mn concentration between the $150 \mathrm{mg} \mathrm{L}^{-1}$ exposure groups from the acute and long-term studies. This indicates the lack of a duration effect with respect to accumulation.

The effect of exposure concentration on Mn accumulation was similar in brain and optic nerve tissue at lower concentrations. The effect of exposure concentration on brain tissue became less obvious between the three highest exposures, whereas the effect on optic nerve continued to show a positive trend reaching a concentration double that observed in the brain. The brain tissue from the long-term study exhibited nearly double the concentration reported in the $150 \mathrm{mg} \mathrm{L}^{-1}$ acute exposure. This suggests that $\mathrm{Mn}$ accumulation in brain tissue is at least partially dependent on duration of exposure. An active transport mechanism is required for Mn to cross the blood 
brain barrier in mammals (Yokel, 2009). It is possible that the mechanism in crustaceans becomes rate-limiting with respect to Mn accumulation in brain tissue at high exposure concentrations. A rate-limiting step such as this could explain the loss of an effect at higher exposure concentrations, and account for the significantly higher concentrations observed in the long-term study. Baden et al. (1999) report similar maximum concentrations of Mn in brain tissue of $N$. norvegicus following a 20-day exposure at $10 \mathrm{mg} \mathrm{L}^{-1}$ dissolved Mn. This high level of accumulation in the brain and nervous tissue coupled with the fact that Mn is a potent neurotoxin, indicates that neurological effects are likely to occur with long-term exposures to this metal. Evidence for neurological effects can be seen as alterations in food searching behavior and tail flip responses in $N$. norvegicus exposed to 10 and $20 \mathrm{mg} \mathrm{L}^{-1} \mathrm{Mn}$ (Baden and Neil, 1998; Krång and Rosenqvist, 2006).

Manganese concentrations in exoskeleton and gill tissue must be interpreted differently than in other tissue types. The exoskeleton is a calcified external tissue and is therefore susceptible to adsorption of non-bioavailable manganese species such as colloidal manganese oxides. The gills are also partly external, as well as being lightly calcified structures. Gills provide the main route of uptake for manganese (Rainbow, 1997) via divalent metal transporters, such as natural resistance-associated macrophage proteins (Nramp) (Culotta et al., 2005). These symporters have been shown to become saturated with respect to Mn uptake in the Neotropical freshwater crab, Dilocarcinus pagei, with possible evidence of a positive adaptive response at higher exposure concentrations (Ponzoni, 2017). Therefore, manganese concentrations reported for gill and exoskeleton tissues represent both potentially accumulated manganese $\left(\mathrm{Mn}^{2+}\right)$ and adsorbed manganese oxides. The background levels in the gills of lobsters serving as controls in our study were very close (20 vs $16 \mathrm{mg} \mathrm{L}^{-1}$ ) to those reported for American lobsters caught offshore 
(Draxler et al. 2005). At low levels Mn is an essential mineral (for review, see Baden and Eriksson, 2006); hence, lobsters will have low concentrations of it for normal homeostasis. It is also a known constituent of the exoskeleton, albeit at much lower levels than calcium or magnesium.

Molting enhanced the accumulation of $\mathrm{Mn}$ in the exoskeleton. A possible explanation for this lies in the molting process of $\mathrm{H}$. americanus. During the premolt stage $\mathrm{Ca}$ is stored in the gastroliths on the lateral walls of the stomach as calcium carbonate. Once a lobster completes ecdysis it begins redistributing these calcium stores to the chelipeds, maxillipeds, and cuticle via hemolymph to facilitate the re-calcification process involved in hardening the cuticle (Factor, 1995). Considering this period of active transport of minerals to the cuticle, and the affinity of $\mathrm{Mn}^{2+}$ to the calcium-binding sites of hemocyanin in the hemolymph, manganese may be distributed simultaneously with Ca to the cuticle and incorporated into the exoskeletal matrix during the process of calcification in the postmolt stage as suggested by Eriksson and Baden (1998). Thus, the concentration of manganese in the exoskeleton is likely representative of the environmental manganese conditions at the time of the lobster's most recent molting and recalcification of the cuticle. Evidence of this can be seen in the extraordinarily high concentrations of Mn in the exoskeletons of the three animals that molted and hardened in the long-term exposure. Lobsters imbibe additional water during ecdysis to facilitate the expansion of their new cuticle and this may provide an additional route of uptake for manganese. Furthermore, some crustaceans are known to use this transport of material to the cuticle as a means of metal depuration (Bergey and Weis, 2007). Such could be the case here. Moreover, the accumulation of $\mathrm{Mn}$ in the exoskeleton of newly molted instars supports the previous work (Eriksson and Baden, 1998; Baden and Eriksson, 2006) in that Mn levels in the cuticle may serve 
as a record of exposure to hypoxia during the postmolt stage. Although the gills and soft tissues may also serve as indicators (Baden and Eriksson, 2006; Draxler et al., 2005), the rapid depuration of $\mathrm{Mn}$ from these tissues would require that animals be dissected or frozen immediately upon collection.

The high exposure concentration of $150 \mathrm{mg} \mathrm{L}^{-1}$ was used in the long-term exposure study to provide the best chance of "forcing" the development of blindness. However, even with this unnaturally high exposure concentration, there was no clear association between blindness and the metal. One conclusion that can be made from this is that the duration of the long-term study was simply not long enough to allow the condition to develop to the point of detection via oscope or histology. Gaten (1988) described a condition in N. norvegicus known as light-induced blindness in which lobsters exposed to direct sunlight for short periods develop lesions in the eye. The condition requires approximately one month after exposure before the lesions are detectible via histological methods (Shelton et al., 1985). To date, there have been no reported cases of light-induced blindness in H. americanus and it is unlikely to occur as the species commonly inhabits shallow water environments with prolonged exposure to sunlight as well as aerial exposure during periods of capture and release as sub-legal animals. It is possible that $H$. americanus requires a longer development period following a stressor to allow physical characteristics of the blindness to manifest to the point of detection.

A secondary mechanism involving the metal remains a possibility. Reddy and Fingerman (1995) showed that Uca pugilator exhibits a decreased ability to disperse black pigments in their chromatophores when exposed to cadmium. Cadmium impedes the release of the black pigmentdispersing hormone, norepinephrine, in the neuroendocrine cells of the eyestalk. Norepinephrine is believed to regulate retinal pigment distribution between dark-adapted and light-adapted 
positions in crustaceans (Fingerman et al., 1981; Gaten, 1988). In the light-adapted position, retinal pigments shield the rhabdom (photosensitive portion of the ommatidium) from excess light. In low-light or dark environments the pigments move into the dark-adapted position to allow more light to reach the rhabdom (Tombes, 1970). U. pugilator shows a suppressed migration of the distal shielding pigment into the light adapted position when exposed to $\mathrm{Cd}$ (Reddy et al., 1997). If Mn or another metal is able to affect the hormonal control of retinal pigment migration in the eyes of $H$. americanus, then exposure to the metal may enhance the susceptibility of ommatidia cells to light-induced damage.

A third explanation for the lack of significance in the development of blindness with Mn exposure is that at environmental concentrations, manganese is not directly involved in the development of idiopathic blindness. If this is true, then alternative environmental stressors should be considered, such as ammonia or sulfide exposure as these are also released from sediments during hypoxia (Cuomo et al. 2005). Prolonged benthic hypoxic events ( $>50$ days) are common during the summer months throughout the inshore waters of Long Island Sound (Cuomo et al. 2005, O’Donnell et al. 2008). Cells with higher energy demands, such as those found in the highly oxygen-dependent optic nerve and ommatidia, tend to more readily cross the threshold from controlled cell death (apoptosis) to uncontrolled enzymatic degeneration (necrosis) leading to tissue damage (Hirata, 2002; Kitazawa et al., 2005). Prolonged exposure to hypoxic environments might account for the necrosis of optic tissue distinctive with this condition (McCormick et al., 2019). Future studies are needed to investigate these potential pathways.

\section{Conclusion}


This is the first study of American lobsters in controlled laboratory exposure to Mn. Although accumulation levels varied among tissues, we show a positive correlation with concentration of exposure in all of the tissues examined. Several tissues appeared to accumulate Mn in relation to the duration of their exposure. Our studies with H. americanus largely corroborate previous studies focused on $N$. norvegicus. The lack of Mn-induced mortality in both acute and long-term exposure studies suggests $\mathrm{Mn}$ is not acutely toxic to H. americanus. The rapid depuration rates reported in $N$. norvegicus and observations made in the current study suggest the retention time of Mn within a given tissue is short enough to avoid significant impairment. The long-term, 7week, exposure to $150 \mathrm{mg} \mathrm{L}^{-1} \mathrm{Mn}$ did not result in significant development of idiopathic blindness. Alternative approaches may need to be considered for future work investigating the condition's etiology, including potential compound effects with Mn as well as hypoxia.

\section{Acknowledgments}

We thank Fisheries Specialists, Inc. for their donation in support of this research to JDS as well as a Student Research Grant to ATO from the Virginia Institute of Marine Science. Lobsters were kindly provided by Dr. Tracy Pugh and her team at the Division of Marine Fisheries, Massachusetts, and Kathleen Reardon and her team at the Dept. Natural Resources, Maine. The Chemistry Department at William and Mary kindly gave us access to their GFAA/FlameAA. We thank the following people for their time or equipment: Dr. Gary Rice, Rita Crockett, Dr. Juliette Smith, Corey Corrick, Michelle Onofrio, and Kristen Prossner. Two reviewers provided helpful criticisms. This is contribution number 3858 from the Virginia Institute of Marine Science. 


\section{References}

Aliko, V., Qirjo, M., Sula, E., Morina, V., Faggio, C., 2018. Antioxidant defense system, immune response and erythron profile modulation in gold fish, Carassius auratus, after acute manganese treatment. Fish Shellfish Immunol. 76:101-109.

https://doi.org/10.1016/j.fsi.2018.02.042

Aller, R.C., 1994. The sedimentary Mn cycle in Long Island Sound: Its role as intermediate oxidant and the influence of bioturbation, $\mathrm{O}_{2}$, and Corg flux on diagenetic reaction balances. J Mar Res. 52(2):259-295. https://doi.org/10.1357/0022240943077091

Aschner, M., Aschner, J.L., 1991. Manganese neurotoxicity: cellular effects and blood-brain barrier transport. Neuroscience \& Biobehavioral Reviews 15.3:333-340. https://doi.org/10.1016/S0149-7634(05)80026-0

Baden, S.P., Eriksson, S.P., 2006. Role, routes and effects of manganese in crustaceans. Oceanography and marine biology. 44:61-83.

Baden, S.P., Eriksson, S.P., Gerhardt, L., 1999. Accumulation and elimination kinetics of manganese from different tissues of the Norway lobster Nephrops norvegicus (L.). Aquat Toxicol. 46(2):127-137. https://doi.org/10.1016/S0166-445X(98)00123-4

Baden, S.P., Neil, D.M., 1998. Accumulation of manganese in the haemolymph, nerve and muscle tissue of Nephrops norvegicus (L.) and its effect on neuromuscular performance. Comp Biochem Phys A. 119(1):351-359. https://doi.org/10.1016/S1095-6433(97)00437$\underline{6}$

Bartlett, R., Mortimer, R.J., Morris, K.M., 2007. The biogeochemistry of a manganese-rich Scottish sea loch: implications for the study of anoxic nitrification. Continental Shelf Res., 27: 1501-1509. https://doi.org/10.1016/j.csr.2007.01.027

Bergey, L.L., Weis, J.S., 2007. Molting as a mechanism of depuration of metals in the fiddler crab, Uca pugnax. Mar Environ Res. 64, no. 5:556-562. https://doi.org/10.1016/j.marenvres.2007.04.009

Brouwer, M., Bonaventura, C., Bonaventura, J., 1983. Metal ion interactions with Limulus polyphemus and Callinectes sapidus hemocyanin: stoichiometry and structural and functional consequences of calcium (II), cadmium (II), zinc (II), and mercury (II) binding. Biochemistry. 22.20, 4713-4723. http://doi.org/10.1021/bi00289a016 
Cuomo, C., Valente, R., Dogru, D., 2005. Seasonal variations in sediment and bottom water chemistry of western Long Island Sound: implications for lobster mortality. J. Shellfish Res. 24: 805-815. https://doi.org/10.2983/0730-8000(2005)24[805:SVISAB]2.0.CO;2

Couper, J., 1837. On the effects of black oxide of manganese when inhaled into the lungs. $\mathrm{Br}$ Ann Med Pharmacol. 1:41-42.

Culotta, V.C., Yang, M., Hall, M.D., 2005. Manganese transport and trafficking: lessons learned from Saccharomyces cerevisiae. Eukaryot Cell. 4(7):1159-1165. https://doi.org/10.1128/EC.4.7.1159-1165.2005

Draxler, A.F., Sherrell, R.M., Wieczorek, D., Lavigne, M.G., Paulson, A.J., 2005. Manganese concentration in lobster (Homarus americanus) gills as an index of exposure to reducing conditions in Western Long Island Sound. J. Shellfish Res. 24: 815-820. https://doi.org/10.2983/0730-8000(2005)24[815:MCILHA]2.0.CO;2

Eriksson, S.P., 2000. Temporal variations of manganese in the haemolymph and tissues of the Norway lobster, Nephrops norvegicus (L.). Aquat Toxicol. 48.2-3:297-307. https://doi.org/10.1016/S0166-445X(99)00035-1

Eriksson, S.P., Baden, S.P., 1998. Manganese in the haemolymph and tissues of the Norway lobster, Nephrops norvegicus (L.), along the Swedish west coast, 1993-1995. Recruitment, Colonization and Physical-Chemical Forcing in Marine Biological Systems. Springer, Dordrecht. 255-264. https://doi.org/10.1007/978-94-017-2864-5_21

Factor, J.R., “Control of Growth and Reproduction.” Biology of the Lobster Homarus americanus, Academic Press Limited, 1995, pp. 218-222.

Fingerman, M., Hanumante, M.M., Fingerman, S.W., Reinschmidt, D.C., 1981. Effects of norepinephrine and norepinephrine agonists and antagonists on the melanophores of the fiddler crab Uca pugilator. J Crust Biol. 16-27. https://doi.org/10.2307/1548202

Gaten, E., 1988. Light-induced damage to the dioptric apparatus of Nephrops norvegicus (L.) and the quantitative assessment of the damage. Mar Freshw Behav Physiol. 13.2:169183. https://doi.org/10.1080/10236248809378671

Hernroth, B., Baden, S.P., Holm, K., André, T., Söderhäll, I., 2004. Manganese induced immune suppression of the lobster, Nephrops norvegicus. Aquat Toxicol. 70(3)223-231. https://doi.org/10.1016/j.aquatox.2004.09.004 
Hirata, Y., 2002. Manganese-induced apoptosis in PC12 cells. Neurotoxicol Teratol. 24.5: 639653. https://doi.org/10.1016/S0892-0362(02)00215-5

Holmes, J. M., Gräns, A-S., Neil, D. M., Baden, S.P., 1999. The effects of the metal ions Mn2+ and Co2+ on muscle contraction in the Norway lobster Nephrops norvegicus (L.). J Comp Physiol B. 169, no 6: 402-410. https://doi.org/10.1007/s003600050236

Krång, A.S., Rosenqvist, G., 2006. Effects of manganese on chemically induced food search behaviour of the Norway lobster, Nephrops norvegicus (L.). Aquat. Toxicol.: 78: 284291. https://doi.org/10.1016/j.aquatox.2006.04.001

Kitazawa, M., Anantharam, V., Yang, Y., Hirata, Y., Kanthasamy, A., Kanthasamy, A.G., 2005. Activation of protein kinase $\mathrm{C} \delta$ by proteolytic cleavage contributes to manganeseinduced apoptosis in dopaminergic cells: protective role of Bcl-2. Biochem pharmacol. 69, no. 1: 133-146. https://doi.org/10.1016/j.bcp.2004.08.035

Luna, L.G., 1968. Manual of histologic staining methods of the Armed Forces Institute of Pathology. Blakiston Division, McGraw-Hill.

Magel, C.R., Shields, J.D., Brill, R.W., 2009. Idiopathic lesions and visual deficits in the American lobster (Homarus americanus) from Long Island Sound, NY. Biol Bull. 217.1: 95-101. https://doi.org/10.1086/BBLv217n1p95

Magnusson, K., Ekelund, R., Dave, G., Granmo, Å., Förlin, L., Wennberg, L., Samuelsson, MO., Berggren, M., Brorström-Lundén, E., 1996. Contamination and correlation with toxicity of sediment samples from the Skagerrak and Kattegat. J Sea Res. 35, no. 1-3: 223-234. https://doi.org/10.1016/S1385-1101(96)90749-2

Maniscalco, A.M., Shields, J.D., 2006. Histopathology of idiopathic lesions in the eyes of Homarus americanus from Long Island Sound. J Invertebr Pathol. 91(2):88-97. https://doi.org/10.1016/j.jip.2005.09.007

McCormick, L.R., Levin, L.A., Oesch, N.W., 2019. Vision is highly sensitive to oxygen availability in marine invertebrate larvae. J Exp Biol. pp.jeb-200899. http://doi.org/10.1242/jeb.200899

Mecray, E.L., Buchholtz ten Brink, M.R., 2000. Contaminant distribution and accumulation in the surface sediments of Long Island Sound. J Coast Res. 16: 575-590. 
Ochs, A.T., Shields, J.D., Hatzipetro, M.S., Somers, B., Castro, K.M., 2018. Development of rapid diagnostic techniques for idiopathic blindness in the American lobster, Homarus americanus, from eastern Long Island Sound. Bull Mar Sci. 94: 945-957. https://doi.org/10.5343/bms.2017.1133

O'Donnell, J., Dam, H.G., Bohlen, W.F., Fitzgerald, W., Gay, P.S., Houk, A.E., Cohen, D.C., Howard-Strobel, M.M., 2008. Intermittent ventilation in the hypoxic zone of western Long Island Sound during the summer of 2004. J. Geophys. Res: Oceans 113: C9. https://doi.org/10.1029/2007JC004716

Oweson, C.A.M., Baden, S.P., Hernroth, B.E., 2006. Manganese induced apoptosis in haematopoietic cells of Nephrops norvegicus (L.). Aquat Toxicol. 77(3):322-328. https://doi.org/10.1016/j.aquatox.2006.01.008

Ponzoni, S., 2017. Manganese tissue accumulation and tyrosine hydroxylase immunostaining response in the Neotropical freshwater crab, Dilocarcinus pagei, exposed to manganese. Invert Neurosci. 17(2): 5. https://doi.org/10.1007/s10158-017-0198-7

Rainbow, P.S., 1997. Trace metal accumulation in marine invertebrates: marine biology or marine chemistry?. J Mar Biol Assoc U.K. 77.1: 195-210. https://doi.org/10.1017/S0025315400033877

Reddy, P.S., Fingerman, M., 1995. Effect of cadmium chloride on physiological color changes of the fiddler crab, Uca pugilator. Ecotoxicol Environ Saf. 31.1: 69-75. https://doi.org/10.1006/eesa.1995.1045

Reddy, P.S., Nguyen, L.K., Obih, P., Fingerman, M., 1997. Effect of cadmium chloride on the distal retinal pigment cells of the fiddler crab, Uca pugilator. Bull Environ contam toxicol. 58, no. 3: 504-510. https://doi.org/10.1007/s001289900363

Shelton, P.M.J., Gaten, E., Chapman, C.J., 1985. Light and retinal damage in Nephrops norvegicus (L.) (Crustacea). Proc Roy Soc London B. 226(1243):217-236. https://doi.org/10.1098/ rspb.1985.0092

Shields, J.D., Wheeler, K.N., Moss, J.A., 2012. Histological assessment of the lobster (Homarus americanus) in the "100 lobsters" project. J Shellfish Res. 31.2: 439-447. https://doi.org/10.2983/035.031.0204 
Tjälve, H., Mejàre, C., Borg-Neczak, K., 1995. Uptake and transport of manganese in primary and secondary olfactory neurones in pike. Pharmacol Toxicol. 77, no. 1: 23-31. https://doi.org/10.1111/j.1600-0773.1995.tb01909.x

Tombes, A.S., 1970. Malacostraca. An Introduction To Invertebrate Endocrinology, Academic Press Incorporated, pp 135-144.

Uglow, R.F., 1969. Haemolymph protein concentrations in protunid crabs-I. Studies on adult Carcinus maenas. Comp Biochem Physiol 30:1083-1090. https://doi.org/10.1016/0010406X(69)91804-0

U.S. EPA. 1996. “Method 3050B: Acid Digestion of Sediments, Sludges, and Soils,” Revision 2. Washington, DC.

Wollast, R., Billen, G. Duinker, J.C., 1979. Behaviour of manganese in the Rhine and Scheldt estuaries: I. Physico-chemical aspects. Estuar Coast Mar Sci. 9, no. 2: 161-169. https://doi.org/10.1016/0302-3524(79)90111-7

Yokel, R.A., 2009. Manganese flux across the blood-brain barrier. Neuromolecular Med. 11.4: 297-310. https://doi.org/10.1007/s12017-009-8101-2 
Table 1: Mean weights (grams) for all extracted tissues in the acute exposure study ( $\mathrm{n}=30$ lobsters).

\begin{tabular}{lccc}
\hline \multicolumn{1}{c}{ Tissue } & ww & dw & ww/dw \pm S.E. \\
\hline Hemolymph & 0.534 & 0.039 & $13.596 \pm 0.42$ \\
Muscle & 0.745 & 0.157 & $4.737 \pm 0.08$ \\
Exoskeleton & 0.657 & 0.427 & $1.537 \pm 0.02$ \\
Gill & 0.651 & 0.071 & $9.154 \pm 0.17$ \\
Hepatopancreas & 1.599 & 0.572 & $2.796 \pm 0.15$ \\
Optic Nerve & 0.083 & 0.016 & $5.145 \pm 0.09$ \\
Brain & 0.052 & 0.009 & $5.749 \pm 0.29$ \\
\hline
\end{tabular}


Table 2: Mean ( \pm S.E.) Mn concentrations from water and tissue samples in the acute exposure study (96 hr). Comparison of average manganese concentrations in tissues across exposure concentrations. Depurated animals were held at $300 \mathrm{mg} \mathrm{L}^{-1}$ for $96 \mathrm{hr}$, then depurated for $72 \mathrm{hr}$ before dissection. Different letters in the same column indicate significant differences at $\mathrm{p}<0.05$ (A-E); differences with depurated animals indicated with different letters $(\mathrm{X}-\mathrm{Z})$. $\mathrm{N}=6$ animals per exposure treatment, $\mathrm{n}=2$ animals in depuration treatment.

\begin{tabular}{|c|c|c|c|c|c|c|c|c|}
\hline \multicolumn{2}{|c|}{ Mn exposure concentration } & \multicolumn{6}{|c|}{ Tissue Mn concentration $\mu \mathrm{g} \mathrm{Mn}^{-1} \mathrm{dw} \pm$ S.E. } & \multirow[b]{2}{*}{ Brain } \\
\hline Nominal & $\begin{array}{c}\text { Measured }\left(\mathrm{mg} \mathrm{L}^{-1}\right) \\
\pm \mathrm{SD}\end{array}$ & Hemolymph & Muscle & Exoskeleton & Gill & Hepatopancreas & Optic Nerve & \\
\hline Control & $<0.05$ & $9.64 \pm 1.11^{\mathrm{AX}}$ & $1.62 \pm 0.07^{\mathrm{AX}}$ & $59.54 \pm 17.84^{\mathrm{AX}}$ & $19.93 \pm 8.28^{\mathrm{AX}}$ & $8.19 \pm 0.98^{\mathrm{AX}}$ & $14.98 \pm 2.14^{\mathrm{AX}}$ & $8.58 \pm 3.26^{\mathrm{AX}}$ \\
\hline $20 \mathrm{mg} \mathrm{L}^{-1}$ & $15.91 \pm 0.13$ & $444.87 \pm 53.54^{\mathrm{B}}$ & $10.86 \pm 0.77^{\mathrm{B}}$ & $153.73 \pm 27.19^{\mathrm{B}}$ & $128.56 \pm 26.75^{\mathrm{B}}$ & $14.96 \pm 1.80^{\mathrm{A}}$ & $64.19 \pm 2.29^{\mathrm{B}}$ & $102.35 \pm 14.37^{\mathrm{B}}$ \\
\hline $80 \mathrm{mg} \mathrm{L}^{-1}$ & $68.04 \pm 0.41$ & $730.44 \pm 55.54^{\mathrm{C}}$ & $62.07 \pm 1.61^{\mathrm{C}}$ & $183.17 \pm 16.87^{\mathrm{B}}$ & $285.46 \pm 36.50^{\mathrm{BC}}$ & $41.48 \pm 7.87^{\mathrm{B}}$ & $163.72 \pm 9.30^{\mathrm{C}}$ & $159.13 \pm 15.28^{\mathrm{C}}$ \\
\hline $150 \mathrm{mg} \mathrm{L}^{-1}$ & $144.18 \pm 0.54$ & $994.39 \pm 58.79^{\mathrm{D}}$ & $77.15 \pm 6.09^{\mathrm{D}}$ & $284.15 \pm 19.67^{\mathrm{B}}$ & $559.61 \pm 67.46^{\mathrm{C}}$ & $56.29 \pm 9.32^{\mathrm{BC}}$ & $263.61 \pm 62.30^{\mathrm{C}}$ & $207.67 \pm 43.41^{\mathrm{C}}$ \\
\hline $300 \mathrm{mg} \mathrm{L}^{-1}$ & $298.26 \pm 3.01$ & $1525.73 \pm 72.87^{\mathrm{EY}}$ & $\begin{array}{c}92.53 \pm \\
6.86^{\mathrm{DY}}\end{array}$ & $632.11 \pm 83.37^{\mathrm{CY}}$ & $1262.21 \pm 116.60^{\mathrm{DY}}$ & $\begin{array}{l}81.38 \pm \\
14.17^{\mathrm{CY}}\end{array}$ & $416.85 \pm 51.04^{\mathrm{DY}}$ & $196.44 \pm 23.07^{\mathrm{CY}}$ \\
\hline Depurated & NA & $449.57 \pm 65.01^{\mathrm{Z}}$ & $60.04 \pm 15.44^{\mathrm{Z}}$ & $935.20 \pm 14.54^{\mathrm{Y}}$ & $643.33 \pm 373.09^{\mathrm{Z}}$ & $32.82 \pm 14.00^{\mathrm{X}}$ & $138.59 \pm 42.21^{\mathrm{X}}$ & $91.34 \pm 56.04^{X Y}$ \\
\hline
\end{tabular}


Table 3: Least squares linear regression for Mn concentration in each tissue in relation to exposure $\left(20,80,150,300 \mathrm{mg} \mathrm{L}^{-1}\right)$ concentrations, excluding controls.

\begin{tabular}{|c|c|c|c|c|c|}
\hline Tissue & Slope & $\mathbf{R}^{2}$ & $\begin{array}{c}95 \% \\
\text { CI } \\
\end{array}$ & $\begin{array}{c}y- \\
\text { intercept }\end{array}$ & $95 \%$ CI \\
\hline Muscle & 0.279 & 0.793 & 0.066 & 16.844 & 11.736 \\
\hline Hepatopancreas & 0.227 & 0.564 & 0.091 & 17.542 & 14.910 \\
\hline Optic Nerve & 1.252 & 0.793 & 0.298 & 38.453 & 52.962 \\
\hline Brain & 0.400 & 0.253 & 0.330 & 104.957 & 56.742 \\
\hline Gill & 4.101 & 0.855 & 0.788 & -31.906 & 139.164 \\
\hline Hemolymph & 3.815 & 0.903 & 0.584 & 396.902 & 104.374 \\
\hline Exoskeleton & 1.778 & 0.740 & 0.466 & 68.751 & 80.511 \\
\hline
\end{tabular}


Table 4: Mean concentrations ( \pm S.D.) of Mn in water and tissue samples ( \pm S.E.) from the $150 \mathrm{mg} \mathrm{L}^{-1}$ treatment in the acute (96 hr) and longterm (7-week) exposure studies. Transformation were used to meet the assumptions of ANOVA. Log transformations were done on gill, hemolymph, and exoskeleton.

\begin{tabular}{|c|c|c|c|c|c|c|c|}
\hline \multicolumn{2}{|c|}{ Mn exposure concentration } & \multicolumn{6}{|c|}{ (Tissue Mn concentration $\mu \mathrm{g} \mathrm{Mn} \mathrm{g}^{-1} \mathrm{dw}$ ) } \\
\hline Treatment Group & Measured \pm SD & Muscle & Hepatopancreas & Brain & Gill & Hemolymph & Exoskeleton \\
\hline $\begin{array}{l}\text { Long-term (0 mg L- } \\
\text { 1) }\end{array}$ & $<0.05$ & $1.80 \pm 0.18^{\mathrm{A}}$ & $11.45 \pm 3.17^{\mathrm{A}}$ & $9.41 \pm 1.11^{\mathrm{A}}$ & $19.91 \pm 8.76^{\mathrm{A}}$ & $5.29 \pm 0.97^{\mathrm{A}}$ & $88.84 \pm 7.44^{\mathrm{A}}$ \\
\hline Acute (150 mg L-1) & $144.18 \pm 0.54$ & $77.15 \pm 6.09^{\mathrm{B}}$ & $62.81 \pm 9.32^{\mathrm{B}}$ & $207.67 \pm 43.41^{\mathrm{B}}$ & $423.23 \pm 67.46^{\mathrm{B}}$ & $994.39 \pm 58.79^{\mathrm{B}}$ & $284.15 \pm 19.67^{\mathrm{B}}$ \\
\hline $\begin{array}{l}\text { Long-term (150 mg } \\
\left.\mathrm{L}^{-1}\right)\end{array}$ & $136.19 \pm 2.21$ & $118.95 \pm 10.96^{\mathrm{C}}$ & $74.82 \pm 7.88^{\mathrm{B}}$ & $410.96 \pm 40.58^{\mathrm{C}}$ & $1721.38 \pm 321.44^{\mathrm{C}}$ & $1052.75 \pm 79.51^{\mathrm{B}}$ & $3355.22 \pm 831.90^{\mathrm{C}}$ \\
\hline
\end{tabular}

*Different letters in the same column indicate significant differences at $\mathrm{p}<0.05$ 
Table 5: Sensitivity and specificity analysis for the o-scope in relation to histological diagnosis.

\section{O-scope assessment}

\begin{tabular}{ll|cc|c} 
& & Blind & Healthy & Total \\
\cline { 2 - 5 } $\begin{array}{l}\text { Histological } \\
\text { assessment }\end{array}$ & Blind & 5 & 2 & 7 \\
& Healthy & 0 & 27 & 37 \\
\cline { 3 - 5 } & Total & 5 & 29 & 34
\end{tabular}




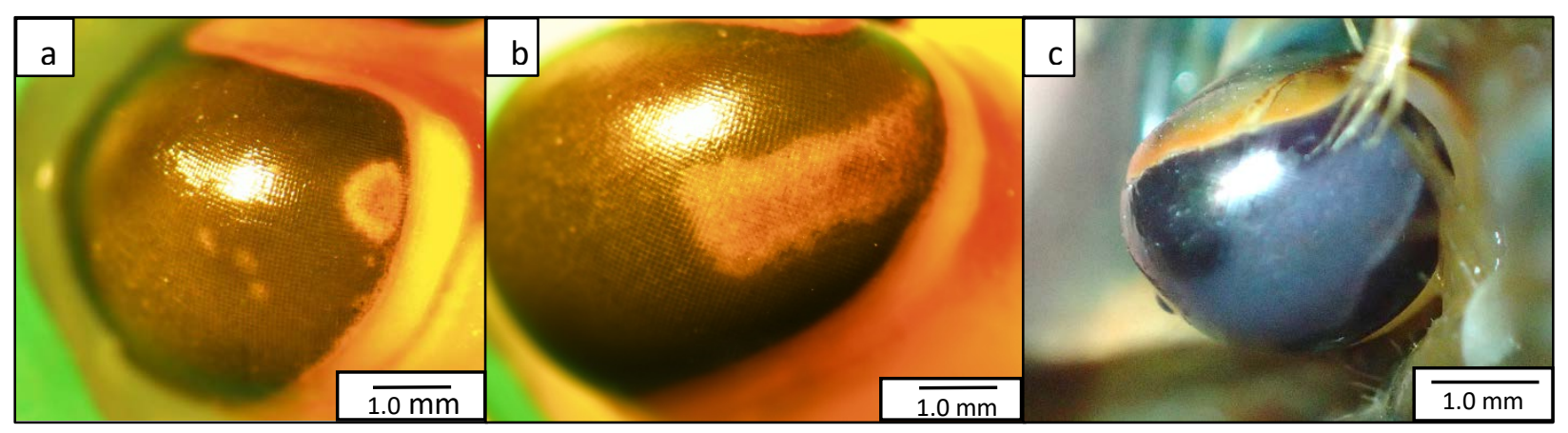

Figure 1: Manifestations of idiopathic blindness at various severities in two eyes from the Gulf of Maine (Ochs, unpublished data) fixed in Bouin's solution, and one eye from Massachusetts (Ochs et al., 2018) from a live animal. (a) A mild case ( $<10 \%$ affected area) in which a small lesion can be observed in the lateral region of the eye. (b) A moderate case (10-30\% affected area) in which the lesion spans from the lateral to medial-lateral regions of the eye. (c) A severe case (>30\% affected area) in which the lesion spans the complete width of the eye in a band-like pattern. 


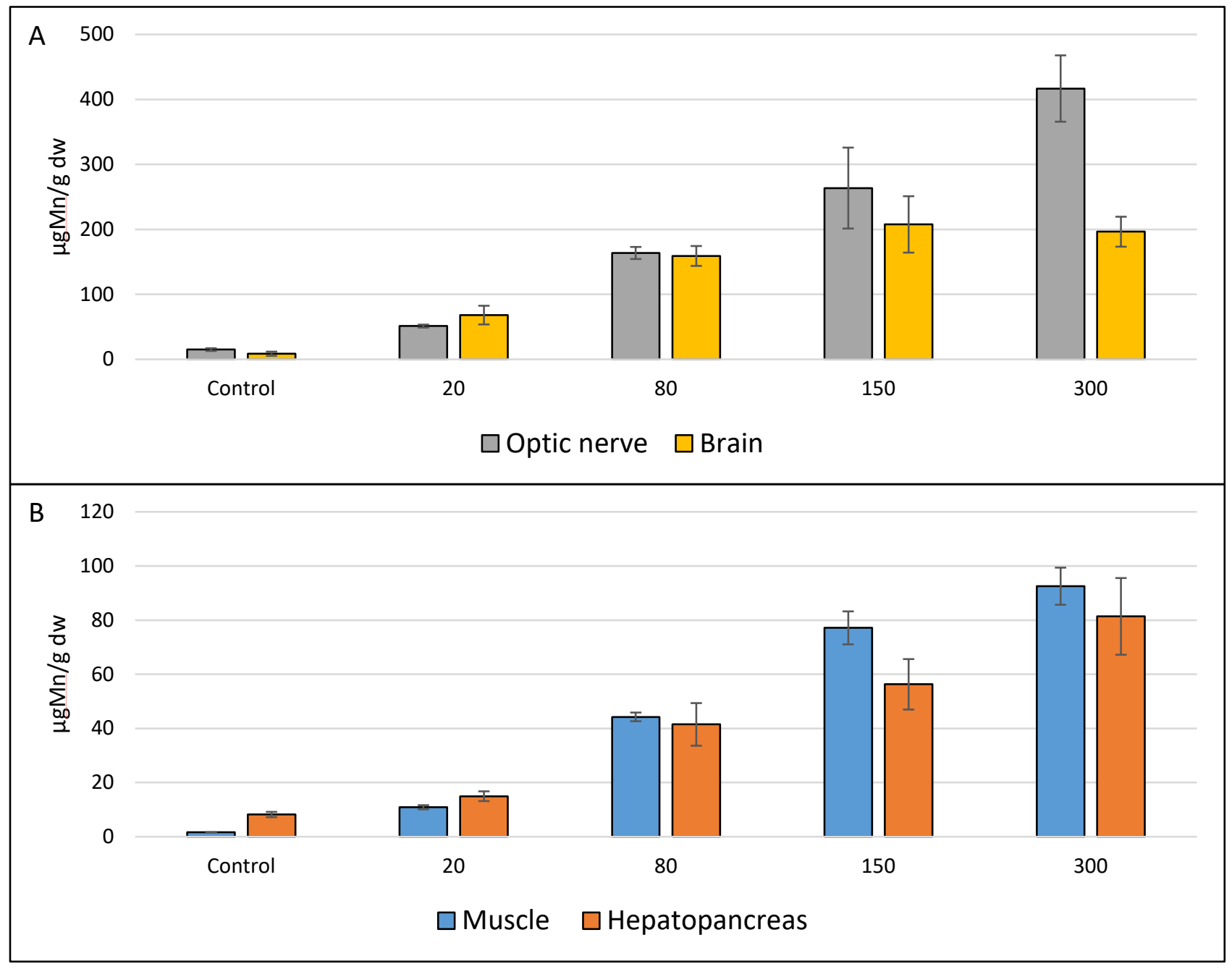

Figure 2: Mean concentrations of $\mathrm{Mn}\left(\mu \mathrm{g} \mathrm{Mn} \mathrm{g}^{-1} \mathrm{dw} \pm \mathrm{se}\right)$ within tissues across exposure concentrations (in $\mathrm{mg} \mathrm{L}^{-1}$ ). A) Accumulation of $\mathrm{Mn}$ in nervous tissues. B) Accumulation of $\mathrm{Mn}$ in muscle and hepatopancreas tissue. Note change in scale of the $\mathrm{Y}$-axis between figures. $\mathrm{N}=6$ animals per treatment. 


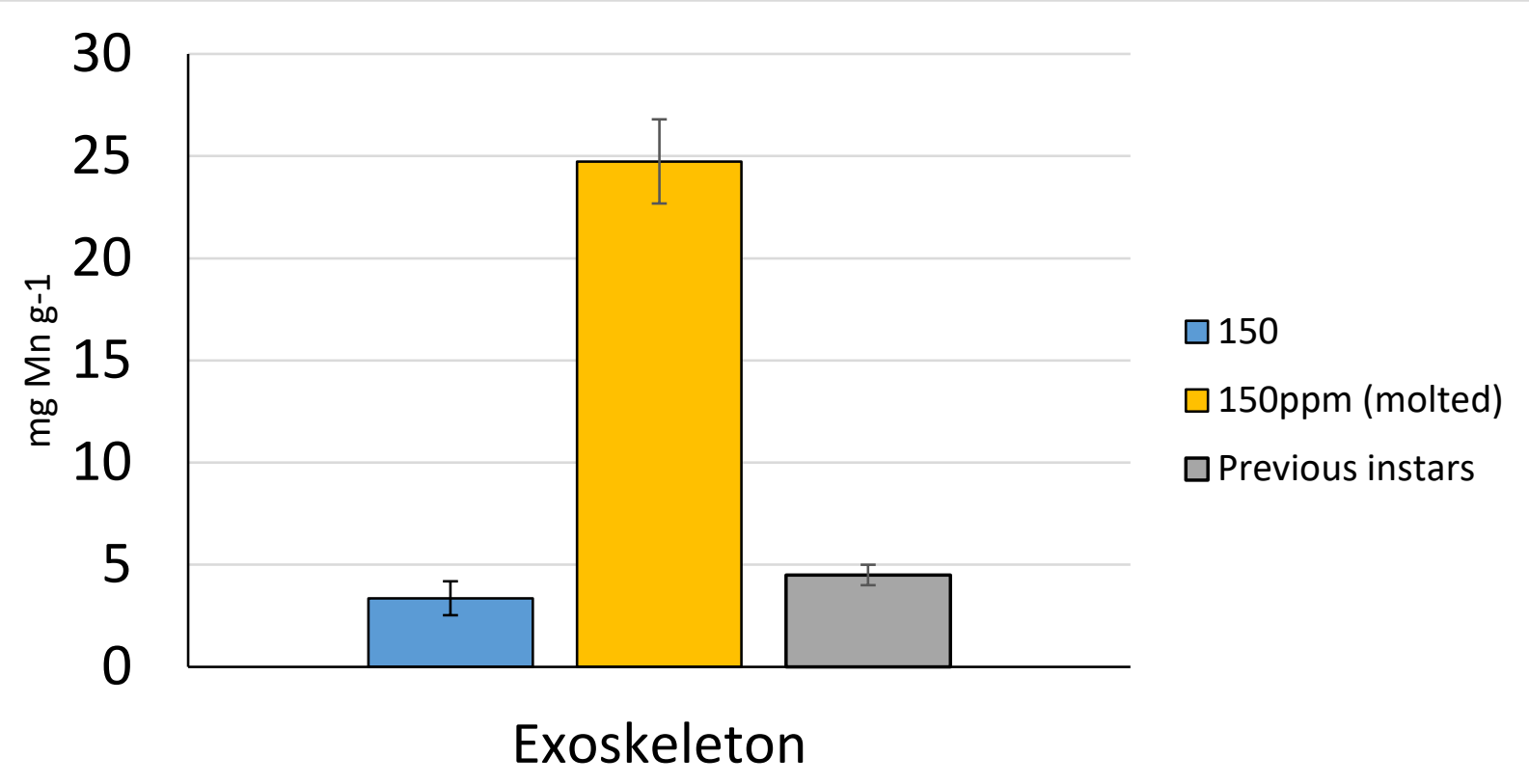

Figure 3: Mean concentrations of $\mathrm{Mn}$ in the exoskeletons of non-molted and molted animals in the $150 \mathrm{mg} \mathrm{L}^{-1}$ exposure group from the long-term study. Mn concentration is reported as mg $\mathrm{Mn}$ $\mathrm{g}^{-1} \mathrm{dw} \pm \mathrm{S}$.E. Previous instars are the old shells of the molted animals collected at the time of molting. Note change in units and scale of the Y-axis compared to Figure 2. 


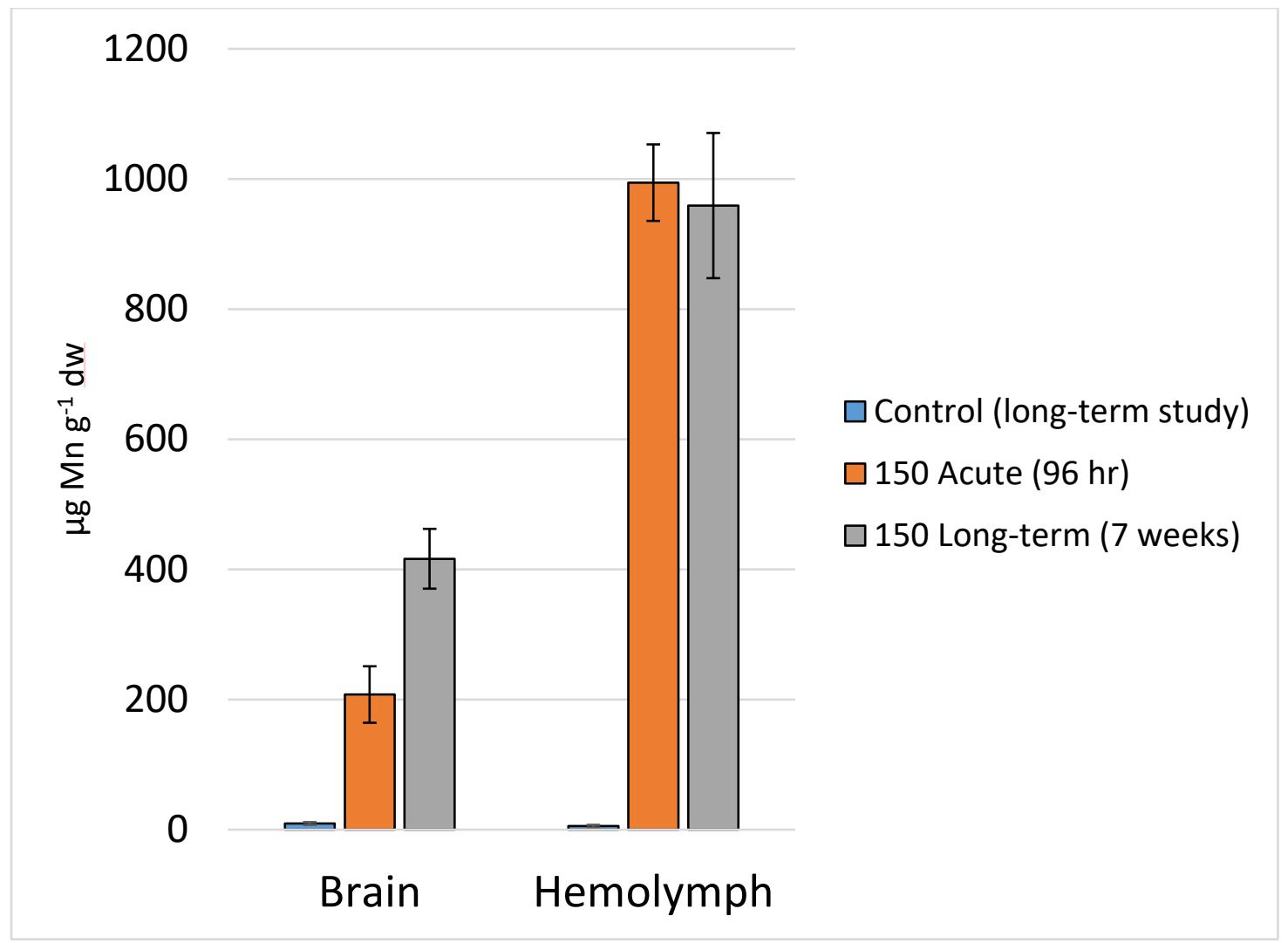

Figure 4: Mean concentrations of $\mathrm{Mn}$ in brain and hemolymph tissues from the Long-term Exposure Study (exposed and control) and concentrations from the $150 \mathrm{mg} \mathrm{L}^{-1}$ treatment of the acute exposure study. Mn treatments were significantly different from controls in both tissue types. Muscle and hepatopancreas showed similar patterns, respectively (data not shown). 


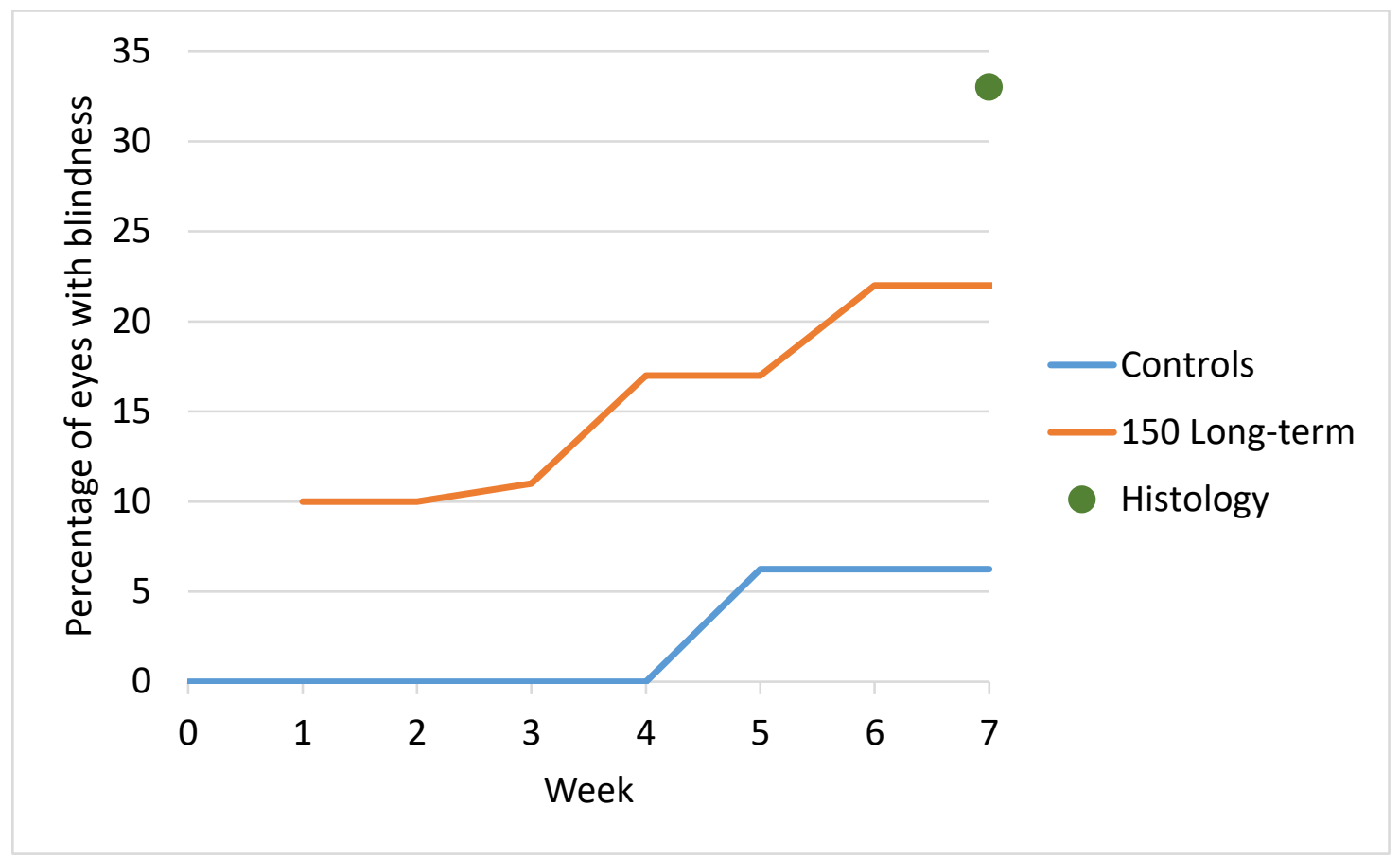

Figure 5: Cumulative assessment of idiopathic blindness in lobsters over the course of the longterm exposure study. The control group is represented by the blue line with an initial prevalence of $0 \%$. The $150 \mathrm{mg} \mathrm{L}^{-1}$ exposure group is represented by the orange line with an initial prevalence of $10 \%$. The grey circle at week 8 represents the prevalence observed in the exposure group via histological assessment. Prevalence is reported as percentage of eyes with blindness. 